$\mathrm{V} \Lambda \mathrm{K} 327.7$

ББК 66.4(0),6

DOI 10.22394/1682-2358-2017-5-45-51

Yu.V. Kulintsev, postgraduate student of the North-East Asia Strategic Issues and SCO Center, Institute of Far Eastern Studies of the Russian Academy of Sciences

\section{DECISION MAKING PROCESS \\ AND THE \\ MECHANISM \\ OF ADJUSTMENT \\ OF INTERNATIONAL DISPUTES WITHIN SCO}

The article studies the principals of SCO working procedures in terms of institutional peculiarities of undertaking decisions. The author analyzes SCO's capacity to control the execution of decisions and ability to exercise the compulsory law enforcement mechanisms to settle the international disputes.

Key words and word-combinations: $\mathrm{SCO}$, regional organization, international relations.
Ю.В. КулиниеВ, аспирант Центра изучения стратегиеских проблем СВА и ШОС, Институт Аальнего Востока РАН

(email: kulintsev.y@ifes-ras.ru)

\section{ПРОЦЕСС}

ПРИНЯТИЯ РЕШЕНИЙ

И МЕХАНИЗМ

УРЕГУ АИРОВАНИЯ

\section{МЕЖАУНАРОАНЫХ СПОРОВ В ШОС}

Аннотация. Рассматриваются принципы работы ШОС с точки зрения институциональных особенностей реализации принимаемых решений. Анализируется возможность организации осуществлять контроль за исполнением решений и использовать механизмы принудительного правоприменения для урегулирования возникающих разногласий.

Ключевые слова и словосочетания: ШОС, региональная организация, международные отношения.

\section{Ш} анхайская организация сотруАничества преАставцяет собой новый взгляА на систему межаународных отношений. ШОС явмяется одной из первых организаций, которые были созданы в начале нового тысячелетия в одном из крупнейших регионов мира в кмючевой период его развития. На международной арене ШОС обладает статусом региональной организации. В современных условиях адаптащии межправительственных организаций к новым вызовам и угрозам представляется важным изучение 
возможностей расширения ШОС и принщипов ее работы, особенно в части, касающейся проџеАур урегулирования споров и механизмов реализации принятых решений.

Известно, что сторонники разАичных политических школ по-разному рассматривают теоретические аспекты взаимодействия государств и политических институтов, подходы к институционализации сотрудничества, а также их общие и особенные черты.Так, известные зарубежные теоретики по исследованию межАународных институтов, например Аж. Мершеймер [1] и А. Рагги [2, р. 14] подчеркивают, что взаимодействие международных институтов и государств носит характер взаимообмена.

Аругая группа ученых (Р. Кохейн, М. Бисон, К. Уолтс) [3; 4] в своих теоретических подходах рассматривает международные институты в качестве производного субъекта межАународных отношений и дополнительного механизма Амя реализаџии государственными акторами своих цемей.

В современных международных отношениях ресурсы региональных организаџий предоставцяют возможности Аля поддержания политических контактов даже в условиях санкций со стороны некоторой части мирового сообщества. Изучение опыта создания и механизмов функционирования межправительственных организаций позволяет адаптировать деятельность международных институтов и интеграционных иниџиатив к новым геополитическим реалиям. В этом отношении ШОС обладает широкими возможностями как один из инструментов всестороннего развития и сотрудничества в Центрально-азиатском регионе, особенно в связи с ростом авторитета организации на международной арене. Аиректор Института Аальнего Востока РАН профессор С.Г. Аузянин пишет: «В последние годы наблюдается значительный рост роли и влияния Шанхайской организаџии сотрудничества как на региональном, так и на глобальном уровнях, который еще 5-7 мет назад не был столь очевиден. Это стало возможным благодаря Аипломатическим достижениям стран ШОС, экономическому прогрессу ее кАючевых участников и институџиональному упорядочению структур внутри организации» $[5$, с. 8$]$.

Шанхайская организация сотрудничества в вопросах поддержания мира, стабильности и межАународной безопасности опирается на принципы взаимного доверия и сотрудничества во всех сферах. Наличие подобного вектора взаимодействия между государствами, заданного Россией и Китаем, явцяется важным вкцадом в систему развития международных отношений.

Аля координаџии деятельности государств - участников Шанхайской организаџии сотрудничества в Аеклараџии о созАании ШОС в п. 11 заложена возможность создания Совета наџиональных координаторов государств-участников [6]. Аанный Совет поручалось учредить на основе Аекларации, а также ранее принятых главами государств документов. Разработан проект Хартии ШОС [7] - основного уставного документа ШОС, правовой фундамент А^я новой межАународной организации. 
В межАународных отношениях процесс принятия решений в межАународных организациях прописывается в уставных документах. В них же указывается, носит ми он рекомендательный или обязатемьный характер. На практике большая часть международных организаций, особенно после 1945 г., применяет принџип голосования большинством голосов, в Аругих используется принцип консенсуса [8], при этом не следует путать понятия «консенсус» и «единогласное решение». ЕАиногласное решение требует проведения формального голосования аля принятия решения, дмя консенсуса же этого не требуется. Иными словами, консенсус означает, что у государств-чменов нет серьезных возражений против принятия решения. ООН опреАеляет консенсус как общее согласие с принимаемым решением без формальных возражений и голосования. Он становится возможным, только когда ни одна из демегаций формально не возразила против консенсуса, даже если некоторые из них не совсем согласны с принимаемым решением или его частью [9].

Осознавая преимущества и недостатки консенсуса, а также учитывая его гибкость, ШОС выбрала его в качестве принципа принятия решения. В Хартии ШОС содержится положение, согласно которому государства-чмены принимают решения на основе согласия без голосования и решение считается принятым, если ни одно из государств-чменов не выдвинуло возражений против его принятия. Решения о приостановке членства или исключения из Организаџии принимаются на основе принџипа консенсуса без учета голоса государства, по которому выносится решение. Аюбой участник вправе высказать свое мнение отдельному аспекту принимаемого решения, что не может считаться препятствием для принятия решения в целом. Высказанное мнение заносится в протокол.

В ст. 16 Хартии ШОС указывается, что государства-чиены, не заинтересованные в конкретном проекте, который выгоден другим участникам, могут не фигурировать в нем, что не будет явмяться препятствием дмя осуществления этого проекта. Более того, эти государства-чиены смогут присоединиться к проекту на более поздней стадии.

МежАународные организации и их органы не принимают обязывающих решений, если это не прописано в их учредительных документах. В Хартии ШОС нет четкого указания на то, что решения органов ШОС носят обязательный характер, но при этом заявляется, что они Аолжны быть претворены в жизнь. Аля обеспечения контроляза наА исполнением решений и урегулирования спорных ситуаций в рамках ШОС предусмотрены механизмы принудительного правоприменения и санкции.

С точки зрения функциональных особенностей специфика ШОС закмючается в том, что ее работа нацелена на различные сферы деятельности. Аругие региональные структуры на пространстве Евразии характеризуются одноплановым функциональным предназначением, представмяя собой исключительно политические или экономические организации либо структуры обеспечения безопасности. Шанхайская же организаџия сотрудничества является комплексной структурой, охватывающей самые различные аспекты политики, эконо- 
мики, культуры, безопасности, и гуманитарных отношений [10] . Спеџифика ШОС состоит также в том, что она поступательно расширяет сферу своей Аеятельности. Организация начала работу с обеспечения безопасности в пограничных районах и постепенно перешла к борьбе с терроризмом, экономическому сотрудничеству, охране окружающей среды и гуманитарному сотрудничеству. Все это позволимо сформировать традиции открытости в работе ШОС. Иными словами, задачи ШОС не были установлены раз и навсегда, а формировались в проџессе эволюџии интеграџионного объединения, поэтому ее функции и исполнительные механизмы также обладают потенциалом дмя расширения.

Указание в учредительных документах механизма принудительного правоприменения решений является обязательным элементом в юридической практике межАународной организации. При этом эффективность и сложность институщиональных механизмов обеспечения соблюдения решений различаются от организации к организаџии.

В проџессе регионального взаимодействия государства после подписания межкправительственных соглашений обязаны выполнять их, и таким образом демонстрировать приверженность соблюдению своих международных обязательств. Сотрудничество в рамках региональных организаций дает возможность независимым государствам использовать возможности международных институтов Аля того, чтобы получить больше информаџию о преАпочтениях и намерениях сторон, а также обеспечить себе дополнительный вес на переговорах для выдвижения и реализации приоритетных задач своего внешнеполитического и соџиально-экономического курса.

Урегулирование международных споров в рамках региональных организаций стало неотъемлемой частью нового миропорядка. В Уставе ООН отмечается высокий потенциал международных региональных и субрегиональных организаций в поддержании международного мира и безопасности. Их важность стала очевиАной после окончания холодной войны, которая значительно ограничивала возможности региональных организаций и объединений. Устав ООН обязывает участников цюбого конфликта, который можкет угрожать межАународному миру и безопасности, разрешать споры с помощью переговоров, посредников, арбитража, юридического урегулирования, обращаясь к региональным организаџиям и объединениям или Аюбыми другими мирными способами.

Взаимодействие на политическом уровне в Аюбой межАународной организации с большей долей вероятности приведет к спорам между ее членами. С учетом этой неизбежной истины разрабатываются учредительные документы всех региональных и международных институтов, а в качестве инструментов мирного разрешения международных споров предлагаются дружественные средства. Некоторые организаџии дополнительно учрежАают юридические институты и комиссии по разрешению споров Аля урегулирования внутренних разногласий, Аругие идут дальше и используют принудительные меры Аля обеспечения выполнения юридических решений, принятых их региональными органами [11]. 
Хартия ШОС преАусматривает ограниченное число среАств урегулирования конфликтов. В случае возникновения споров и разногласий по поводу интерпретации или применения Хартии, государства-члены должны разрешать их посреАством консультаџий и переговоров, альтернативных вариантов не предусмотрено. Аогично предположить, что если согласие межАу госуАарствами по поводу их позиџий не будет достигнуто, то они будут искать альтернативные способы решения спорных вопросов. Ограниченность всего Аишь двумя способами урегулирования разногласий в ШОС вызывает сожацение, особенно с учетом того, что все большее распространение получают международные региональные юридические органы. В современных условиях практически каждая региональная организаџия имеет в своем составе судебный орган, который призван разрешать споры межАу его чменами. Подобную практику могла бы перенять и ШОС, получив, таким образом, дополнительный инструмент достижения поставленных цемей и реализации принятых решений.

В Хартии ШОС указывается на различие межАу исполнением решения и контролем наА его выполнением. Решения, принятые органами ШОС, Аолжны быть выполнены странами-чменами в соответствии с их наџиональным законодательством. Контроль наА выполнением обязательств возлагается на органы ШОС в соответствии с их компетенциями. Подобная формулировка предоставляет государствам-чиенам некоторую свободу действий в возможностях применения решений согласно собственным юридическим законам. Хотя такой подход потенџиально снижает эффективность исполнения решений Организаџии, в нем учтен тот факт, что механизм обеспечения соблюдения решений межкународных договоренностей в регионацьных организациях не всегда является мегко реализуемым. От стран-членов требуется наличие значительной политической воли, чтобы подобный механизм эффективно работал. Контроль наА выполнением обязательств исполняется соответствующими органами, при этом в Хартии ШОС не указано, какие именно органы его осушествляют. В случае невыполнения каким-либо государством своих обязательств соответствующие органы могут выступить с инициативой о принятии мер к этому государству. Окончательное решение утверждается главами государств.

В современных международных организациях распространенной формой санкций является приостановление чменства и исключение из организаџии. В Хартии ШОС также упомянуты эти два понятия. Чиенство в ШОС госуАарства, которое нарушает поможения Хартии и систематически не выполняет своих обязательств, может быть приостановлено решением Совета глав государств. Решение об искмючении из ШОС выносят, если это государство продолжит нарушать свои обязательства [1, с. 13]. ОАнако условия применения данного положения неоднозначны.

В теории межАународных отношений существует принџип так называемых подразумеваемых правомочий, когда международные организаџии побужАают государства-чмены к выполнению обязательств через применения санкщий [12]. Например, Пакт Аиги арабских государств ( $А$ АГ) не 
предусматривает использование такой меры как приостановление чменства. ОАнако $А$ пГ приостановила чменство Египта в 1979 г. и переместила штаб-квартиру организации из Каира в Тунис в качестве санкций за подписание мирного договора с Израилем. Были применены другие Аипломатические и экономические санкции. Аипломатическая изоляџия преАполагала прекращение чиенства Египта в $\Lambda$ АГ, вкцючая членство в Аочерних структурах (Организация арабских стран-экспортеров нефти, Арабский валютный фонА) [13, с. 111-155]. В этом случае, вынося решение, международная организация ссылалась на принцип подразумеваемых полномочий.

Региональная организация имеет право применять меры принудительного характера выполнения своих международных обязательств в рамках Устава ООН и принџипа подразумеваемых правомочий. Эти меры могут вкмючать отказ в праве выступать на встречах, отказ в праве голосования, в возможности представлять своих кандидатов на мюбой пост в организаџии ици помучать какую-либо выгоду от участия в организации. Наложение подобных санкций не требует предварительного согласования с Советом Безопасности $\mathrm{OOH,} \mathrm{в} \mathrm{противном} \mathrm{случае} \mathrm{это} \mathrm{привело} \mathrm{бы} \mathrm{к} \mathrm{нарушению} \mathrm{принципов} \mathrm{фун-}$ кщионирования региональных организаций и снизимо возможности региональной организации в принудительном правоприменении международных договоренностей, а также повлекмо за собой дальнейшее нежелательное помитическое вмешательство в дела региональной организации, что повлияло бы на ее эффективность.

ОАнако, если государство или организаџия, имеющие статус наблюдате$\Lambda я$, совершат действие или выступят с заявлением, направленным против Организации, решений органов ШОС или принџипов, указанных в Хартии

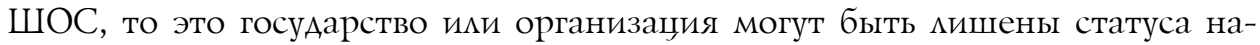
блюдателя в порядке, указанном ранее. Принятое решение направляется Генеральным секретарем ШОС соответственному государству или организаџии в течение недели. Государство или организаџия, имеющие статус наблюдателя и желающие отказаться от него, направцяют соответствующее уведомление Генеральному секретарю, который через СНК информирует Совет министров иностранных де $и$ Совет глав государств. Государство или организаџия теряет свой статус наблюдателя с даты, указанной в уведомлении, если в нем не прописано иное. В случае изменения правоотношений межАу государством мибо организаџией и ШОС они автоматически теряются статус наблюдателя.

Ао сих пор сушественных разногласий между государствами - чменами ШОС кибо невыполнения ими своих обязательств отмечено не было, и механизмы принудительного правоприменения и санкции в раках ШОС пока остаются незадействованными.

Развитие «Шанхайской пятерки» и создание ШОС стало возможным в результате особой формы международных отношений, сложившихся на евразийском пространстве. ГАавы государств - чменов новой региональной организаџии стали смотреть на вопросы торгово-экономического сотрудничества и 
обеспечения глобальной безопасности, опираясь искмючительно на принџипы взаимного доверия и уважения.

В настоящее время ШОС является полноценной международной организащией со своей институџиональной структурой, правовой основой и высоким региональным авторитетом. Статус наблюдателя Генеральной Ассамблеи ООН свидетельствует о ее признании мировым сообществом. Ведущая роль ШОС в регионе подтверждается желанием других государств присоединиться к ней в качестве наблюдателя или партнера по диалогу.

МежАународно-правовые основы институџионального оформления организаџии были заложены Хартией ШОС, и, хотя в структуре организаџии не существует постоянного органа, ответственного за разрешение споров межАу государствами-чиенами, Хартия выступает в качестве основного механизма, позволяющего урегулировать на региональном уровне любые разногласия и споры между государствами-чиенами, что способсствует поддержанию общего межАународного мира и безопасности.

\section{Библиографический список}

1. Mearsheimer J. The False Promise of International Institutions // International Security. 1994/95. № 19. P. 5-49.

2. Ruggie J. Multilateralism: the anatomy of an institution / In eds. by J. Ruggie Multilateralism Matters. N.Y., 1993.

3. Keohane R. International Institutions: Two Approaches // International Studies Quarterly. 1988. № 32.

4. Beeson M. Regionalism and Globalization in East Asia. Palgrave Macmillan, 2007.

5. Лузянин С.Г. Значение Центральной Азии и ШОС: экспертный дискурс // Перспективы развития ШОС с точки зрения национальных интересов России / отв. ред., сост. Ю.В. Морозов. М., 2016.

6. Декларации о создании ШОС. Региональное экономическое сотрудничество ШОС.

URL: http://www.sco-ec.gov.cn/crweb/scor/info/Article.jsp?a_no=719\&col_no=66

7. Хартия ШOC. URL: http://infoshos.ru/ru/?id=33

8. White N.D. The Law of International Organizations. Manchester University Press, 1996.

9. Журнал Организации Объединенных Наций. 1987. № 174. URL: http://www.un.org/ru/ sections/documents/journal-united-nations/index.html

10. Лузянин С.Г. Шанхайская Организация Сотрудничества 2013-2015. Прогнозы, сценарии и возможности развития. М., 2013.

11. Sands P., Mackenzie R., Shany Y. (ed.). Manual on International Courts and Tribunals. Butterworths, 1999.

12. Монталдо М. Особенности международного законодательства и подразумеваемые полномочия международных организаций. М., 1970.

13. Clements F.A. Arab Regional Organizations. Oxford: Clio Press, 1992. 